\title{
Inter-annual variations over a decade of primary production of the seagrass Posidonia oceanica
}

\author{
W. Champenois (1), A. V. Borges (1)* \\ Chemical Oceanography Unit, University of Liège, Liège, Belgium
}

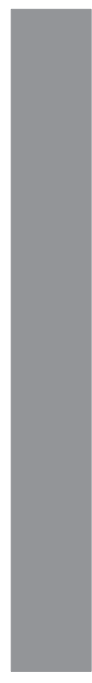

\begin{abstract}
We acquired quasi-continuous measurements of community gross primary production (GPP) by mass balance of $\mathrm{O}_{2}$ measured on a mooring, from August 2006 to October 2016 over a Posidonia oceanica meadow (10 m depth) in the Bay of Revellata (Corsica). Over the 2006-2016 period, annual GPP averaged $88 \mathrm{molO}_{2} \mathrm{~m}^{-2} \mathrm{yr}^{-1}$ and ranged from 61 to $108 \mathrm{molO}_{2} \mathrm{~m}^{-2} \mathrm{yr}^{-1}$. The $2 \mathrm{yr}$ with the lowest annual GPP (2007 and 2015) were characterized by a low occurrence of fall-winter storms, probably leading to the accumulation of leaf litter in fall and early winter; we hypothesize this might have led to occultation of benthic macro-algae. Among the other years, the inter-annual variability of GPP was related to changes during the February-August period, as GPP was repeatable among years during the September-January period. For the February-August period, inter-annual variations of GPP were correlated to chlorophyll $a(\mathrm{Chl} a)$, solar radiation (SR) and water temperature. Computed phytoplankton GPP corresponded to a small fraction of community GPP, so the relation between GPP and Chl a probably reflected inter-annual variations of a common driver that we hypothesize to be nutrient inputs. The correlation of GPP with SR shows that light availability contributed to inter-annual variations of the development of $P$. oceanica. The positive relation between GPP and temperature was consistent with the fact that the observed temperatures in the Bay of Revellata were during the study period within the comfort range for the growth of $P$. oceanica, despite an increase of water temperature of $0.7^{\circ} \mathrm{C}$.
\end{abstract}

Posidonia oceanica is a marine phanerogam (magnoliophyta) endemic of the Mediterranean Sea that forms vast and lush meadows, and ranks among the most productive ecosystems on Earth (Duarte and Chiscano 1999; Duarte et al. 2010). There is a large uncertainty in the estimation of the total surface area occupied by $P$. oceanica meadows (Bonacorsi et al. 2013), that range between $25,000 \mathrm{~km}^{2}$ and $50,000 \mathrm{~km}^{2}$ corresponding to $1-2 \%$ of the total surface area of the Mediterranean Sea (Bethoux et al. 1986; Pasqualini et al. 1998). The surface area of meadows that has been effectively mapped is $12,247 \mathrm{~km}^{2}$, although substantial portions of the coastlines in the Mediterranean Sea have not been actually mapped (Telesca et al. 2015). The P. oceanica meadows border nearly of all the coastlines of the Mediterranean Sea, and are present from depths between $\sim 1 \mathrm{~m}$ and $\sim 40 \mathrm{~m}$. P. oceanica can survive within a wide range of salinity (21.5-48.0) and water temperature $\left(10-30^{\circ} \mathrm{C}\right) \quad$ (Meinesz et al. 2009; Tomasello et al. 2009), but require clear water with a low turbidity, so are absent close to the delta of large rivers (Nile, Rhône, ...) (Gobert et al. 2006). The extent of the meadows of $P$. oceanica

\section{*Correspondence: alberto.borges@uliege.be}

Additional Supporting Information may be found in the online version of this article. is decreasing (Boudouresque et al. 2009; Marbà et al. 2014; Telesca et al. 2015), as most other seagrasses worldwide (Waycott et al. 2009).

$P$. oceanica meadows have an important ecological but also economic value (Costanza et al. 1997) estimated to $172 € \mathrm{~m}^{-2} \mathrm{yr}^{-1}$ by Vassallo et al. (2013), as they provide numerous ecosystem goods and services (Boudouresque et al. 2006; Campagne et al. 2015). P. oceanica meadows are ecosystem engineers that transform and stabilize the coastal environment (Boudouresque et al. 2006). The leaves of $P$. oceanica slowdown water currents, trapping suspended particles (Dauby et al. 1995; Gacia and Duarte 2001), and the resulting lower turbidity allows a better light penetration (Carr et al. 2010). The sediment accumulation combined to the root and rhizome growth leads to the formation of the "matte" (Boudouresque and Meinesz 1982). The detached leaves in autumn will in part accumulate in the shore forming "banquettes" that can be more than $1 \mathrm{~m}$ high, several meters large, and several hundred meters long (Mateo et al. 2003). These structures protect beaches from erosion by the winter-time storms (Guala et al. 2006). The matte and banquettes stabilize the shoreline and in certain cases the $P$. oceanica meadows make structures equivalent to coral reef barriers (Boudouresque et al. 2006). P. oceanica meadows are 
habitat, breeding and spawning ground, and nursery for numerous species, and host a large biodiversity; 400 species of flora, several thousand species of fauna, totaling $\sim 20 \%$ of the species inventoried in the Mediterranean Sea (Boudouresque et al. 2006). Furthermore, $P$. oceanica meadows also contribute to sustain production and biodiversity of adjacent ecosystems, with economic consequences, in particular with regards to fisheries (Boudouresque et al. 2006).

$P$. oceanica meadows are also carbon sinks (Romero et al. 1994; Mateo et al. 1997; Pergent et al. 1997). The matte is mainly composed of dead roots, rhizomes and leaves, and to a lesser extent of sedimented particles from the water column, overall corresponding to organic carbon that is relatively refractory to biological degradation, that, in addition, is compacted by a cement of calcium carbonate (Boudouresque and Meinesz 1982). Despite microbial degradation mainly in the first millimeters of the matte where $\mathrm{O}_{2}$ is present (Holmer et al. 2003), a large fraction of the organic carbon in the matte will be sequestered for millennia, acting as a sink for carbon, nitrogen, and phosphorus (Romero et al. 1994; Mateo et al. 1997, 2006; Pergent et al. 1997). About 30\% of organic carbon from net primary production of $P$. oceanica meadows is stored on the long-term in the matte (Mateo et al. 1997, 2006; Pergent et al. 1997; Duarte et al. 2005). This storage only lasts as long as the $P$. oceanica meadow is healthy; in case of loss of the seagrass shoots, currents and waves will desegregate the matte and the released organic matter might be remineralized by bacteria (Kennedy et al. 2010; Fourqurean et al. 2012).

Seagrass meadows are threatened by several human stressors, and these ecosystems are decreasing globally (Duarte 2002; Duarte et al. 2005; Waycott et al. 2009), including P. oceanica (Marbà et al. 2014), with a decrease in surface coverage estimated to $34 \%$ during the last $50 \mathrm{yr}$ (Telesca et al. 2015). $P$. oceanica meadows are threatened by eutrophication (waste water and aquaculture), physical destruction from shoreline construction, anchoring and trawling, and climate change (sealevel rise and warming). During the last decades, the human population as well as tourism have increased in the regions bordering the Mediterranean Sea, with an increase of urbanization on shorelines. This has led to a direct destruction of $P$. oceanica meadows, as well as an increase of nutrient inputs to the coastal zone from wastewater (Boudouresque et al. 2009). Eutrophication will have a double negative impact on $P$. oceanica: development of phytoplankton leading to a decrease of water transparency; proliferation of epiphytes growing on $P$. oceanica leaves (Boudouresque et al. 2006). The epiphytes have a much faster growth than the $P$. oceanica leaves and will compete with $P$. oceanica for light and nutrients (Boudouresque et al. 2006). Organic matter and nutrients released from aquaculture and wastewater will also strongly affect $P$. oceanica meadows leading a decrease of the density of shoots, and changes of the sediment biogeochemistry, as well as in benthic fauna assemblages and bacterial communities (Holmer and Kristensen 1992; La Rosa et al. 2001; Holmer and Frederiksen 2007; Papageorgiou et al. 2009; Mirto et al. 2014). Anchoring and trawling also cause damage of $P$. oceanica meadows by the physical removal of shoots, and it takes up to $100 \mathrm{yr}$ depending on extent of damage for the meadow to recover from such damage (Gonzales-Correa et al. 2005; Abadie et al. 2015). The slow recovery is due to the slow growth of $P$. oceanica but also to the changes in the sediment physico-chemistry related to the destruction of roots and rhizomes that will be unfavorable to the recolonization (Abadie et al. 2016). Some invasive plant species such as Caulerpa sp. and Lophocladia lallemandii can compete with $P$. oceanica (Boudouresque et al. 2009), although they thrive in already degraded meadows with a low shoot density (Williams 2007). Finally, global and climate changes might affect the survival of $P$. oceanica. The lower depth limit of the meadows corresponds to the light compensation depth (Olesen et al. 2002), that will shift with sea-level rise. $P$. oceanica is also sensitive to high water temperature, and shoot mortality increases during extreme warm events $\left(>28.0^{\circ} \mathrm{C}\right)$ during heat waves at the end of summer (Diaz-Almela et al. 2007; Marbà and Duarte 2010), that might increase with global warming (Jordà et al. 2012).

Primary production of $P$. oceanica is notoriously variable with depth and also across temporal scales: sub-daily, seasonal (Bay 1984; Pergent-Martini et al. 1994; Alcoverro et al. 1995; Gobert et al. 2006), and year-to-year (Champenois and Borges 2012). The variability of gross primary production (GPP) in $P$. oceanica can be due to natural causes such as variations of incident solar radiation (SR), that varies day-to-day due to cloudiness (Gazeau et al. 2005) and seasonally (Alcoverro et al. 1995; Champenois and Borges 2012), or as a result from human stressors such as eutrophication (Apostolaki et al. 2010). Consequently, we hypothesize that high frequency monitoring of GPP could be used to diagnose the health status of $P$. oceanica meadows, and its long-term evolution. Further, inter-annual variations of GPP in response to extreme weather events (heat wave, cold spell, extreme storm, abnormal mild weather, ...) can provide natural tests to check how ecosystems could respond in future to global and climate change (Jentsch et al. 2007).

The aim of the present paper is to investigate if longterm changes (decline or increase) of GPP occurred in a $P$. oceanica meadow (at $10 \mathrm{~m}$ depth) based on a large dataset spanning a decade (2006-2016), as contribution to long-term observations of the meadow in the Bay of Revellata (Corsica) under the STARE-CAPMED initiative. We also quantify the inter-annual variability of GPP which has been seldom investigated in marine ecosystems, and to our best knowledge never before in seagrass meadows. We investigate the possible causes of these inter-annual variations of GPP with the analysis of additional environmental data such as water temperature, wind speed, precipitation, SR, and phytoplankton biomass. Such analysis can provide insights into the response of GPP in P. oceanica meadows 
to future human induced changes in environmental conditions, and we particularly discuss the response to warming.

\section{Material and methods}

A mooring was deployed from August 2006 until October 2016 at $10 \mathrm{~m}$ depth over a $P$. oceanica meadow $\left(8.725^{\circ} \mathrm{E}\right.$ $42.580^{\circ} \mathrm{N}$ ) in front of the Stareso research station (Corsica, France). The mooring was equipped with three Aanderaa optodes (3835) mounted on Alec Instrument data-loggers, located at $4.5 \mathrm{~m}, 7.0 \mathrm{~m}$, and $9.5 \mathrm{~m}$ depth, that recorded $\mathrm{O}_{2}$ saturation and water temperature on an hourly basis. Data retrieval, maintenance, and stability check of optodes was done every 3 months. The computation of GPP, community respiration (CR), and net community production (NCP) is based on the Odum (1956) method that relies on the changes of vertically integrated $\mathrm{O}_{2}$ content $\left(\mathrm{Q}_{\mathrm{O} 2}\right.$ in $\left.\mathrm{mmol} \mathrm{m}^{-2}\right)$ derived from the vertical integration of volumetric concentration measurements at the 3 depths $(4.5 \mathrm{~m}, 7.0 \mathrm{~m}$, and $9.5 \mathrm{~m})$.

Daily integrated $\mathrm{CR}\left(\mathrm{mmol} \mathrm{O}_{2} \mathrm{~m}^{-2} \mathrm{~d}^{-1}\right)$ is computed according to:

$$
\mathrm{CR}=\left(\sum\left(\left(\mathrm{Q}_{\mathrm{O} 2 \mathrm{n}}\right)_{t+1}-\left(\mathrm{Q}_{\mathrm{O} 2 \mathrm{n}}\right)_{t}\right)+\sum \mathrm{FO}_{2 \mathrm{n}}\right) / H_{\mathrm{n}} \times 24
$$

where $\left(Q_{\mathrm{O} 2 \mathrm{n}}\right)_{t+1}-\left(Q_{\mathrm{O} 2 \mathrm{n}}\right)_{t}$ is the change in $Q_{\mathrm{O} 2}$ during nighttime $\left(Q_{\mathrm{O} 2 \mathrm{n}}\right)$ between two hourly intervals $(t), \mathrm{FO}_{2 \mathrm{n}}$ is the airsea $\mathrm{O}_{2}$ exchange at each $t$ during night-time computed using the Ho et al. (2006) gas transfer parameterization as function of wind speed, and $H_{\mathrm{n}}$ is the night-time duration in hours.

Daily integrated GPP $\left(\mathrm{mmol} \mathrm{O} \mathrm{m}^{-2} \mathrm{~d}^{-1}\right)$ is computed according to:

$$
\mathrm{GPP}=\sum\left(\left(Q_{\mathrm{O} 2 \mathrm{~d}}\right)_{t+1}-\left(\mathrm{QO} 2 \mathrm{~d}_{t}\right)+\sum \mathrm{FO}_{2 \mathrm{~d}}-\mathrm{CR}\right.
$$

where $\left(Q_{\mathrm{O} 2 \mathrm{~d}}\right)_{t+1}-\left(Q_{\mathrm{O} 2 \mathrm{~d}}\right)_{t}$ is the change in $Q_{\mathrm{O} 2}$ during daytime $\left(Q_{\mathrm{O} 2 \mathrm{~d}}\right)$ between two $t, \mathrm{FO}_{2 \mathrm{~d}}$ is the air-sea $\mathrm{O}_{2}$ exchange at each $t$ during day-time.

Daily integrated NCP is computed as the sum of daily integrated GPP and daily integrated CR.

The computed GPP value integrates all the components of the meadow, planktonic and benthic, although Champenois and Borges (2012) showed it is largely dominated by the benthic compartment ( $P$. oceanica, epiphytic and benthic microand macro-algae). We obtained 2821 GPP measurements from 08 August 2006 to 27 October 2016 (Supporting Information Fig. S1). Ancillary data for the analysis of inter-annual GPP variations were: sea surface temperature (SST), chlorophyll $a(\mathrm{Chl} a)$, wind speed, SR, and precipitation. SST was derived from temperature measurements over the top of the canopy (optode located at $9.5 \mathrm{~m}$ depth). Water temperature was measured at the three depths, and the water column was always isothermal, so we chose to use the data acquired just above the $P$. oceanica canopy. Monthly Chl $a$ values were derived from moderate-resolution imaging spectroradiometer (MODIS) and processed level-3 data were retrieved from the Giovanni data portal (https://giovanni.gsfc.nasa.gov/ giovanni/) for a quadrant delimited by $42.579 ; 42.591^{\circ} \mathrm{N}$ and $8.723 ; 8.728^{\circ} \mathrm{E}$; for a quality assessment and calibration of the Chl a MODIS products refer to Kwiatkowska et al. (2008) and Meister et al. (2012). Wind speed was measured with a Thies Clima anemometer on top of one of Stareso buildings and data were converted from the measurements height $(11.8 \mathrm{~m})$ to a reference height $(10 \mathrm{~m})$ based on Johnson (1999). SR (duration in $\mathrm{h}$ with $\mathrm{SR}>120 \mathrm{~W} \mathrm{~m}^{-2}$ ) and precipitation data were measured at the Calvi airport $\left(8.793^{\circ} \mathrm{E}\right.$ $42.524^{\circ} \mathrm{N}$ ) and retrieved from the Météo France data portal (http://www.meteofrance.com/climat/france/calvi/20050001/ releves). Analysis of inter-annual variations was based on monthly averages for GPP, SST, Chl $a$, wind speed, and monthly cumulated values for SR and precipitation. The annual cycle was determined from the seasonal cycle of $P$. oceanica biomass and defined from $1^{\text {st }}$ November to $31^{\text {st }}$ October, since leaf biomass is typically lowest in November after the autumn leaf shedding. Shoot density was measured by counts and leaf biomass on 10 shoots collected by SCUBA divers as described by Champenois and Borges (2012).

Statistical analysis was done with Graphpad Prism 6 software, using either Student $t$-test or ANOVA at the 0.05 level. A principal component analysis (PCA) was performed using the prcomp function in $\mathrm{R}$ software (https://www.r-project.org/); data were scaled to zero mean and unit variance, prior to analysis.

The hourly dissolved oxygen and water temperature timeseries are available as Supporting Information material.

\section{Results and discussion}

\section{Seasonal and inter-annual variations of GPP in the $P$. oceanica meadow in the Bay of Revellata}

Individual GPP values $(n=2821)$ varied over four orders of magnitude, ranging between $0.4 \mathrm{mmol} \mathrm{O}_{2} \mathrm{~m}^{-2} \mathrm{~d}^{-1}$ and $1818 \mathrm{mmol} \mathrm{O}_{2} \mathrm{~m}^{-2} \mathrm{~d}^{-1}$ (Supporting Information Fig. S1). CR and NCP were strongly correlated to GPP (Supporting Information Fig. S2), in agreement with previous investigations of marine community metabolism (Duarte and Agustí 1998). CR and NCP represented for the whole data-set $27 \%$ and $73 \%$ of GPP, and NCP averaged $23 \pm 23 \mathrm{molO}_{2} \mathrm{~m}^{-2} \mathrm{yr}^{-1}$, showing that the $P$. oceanica meadow was net autotrophic at annual scale, in agreement with previous investigations of community metabolism in P. oceanica meadows (e.g., Frankignoulle and Bouquegeau 1987; Barrón et al. 2006; Duarte et al. 2010). Net autotrophy was also confirmed by an overall $\mathrm{O}_{2}$ oversaturation that averaged 104\% (range 66-287\%) during the study period (Supporting Information Fig. S1). As previously described by Champenois and Borges (2012), whatever the season, a daily variation of $\mathrm{O}_{2}$ concentration was observed, 


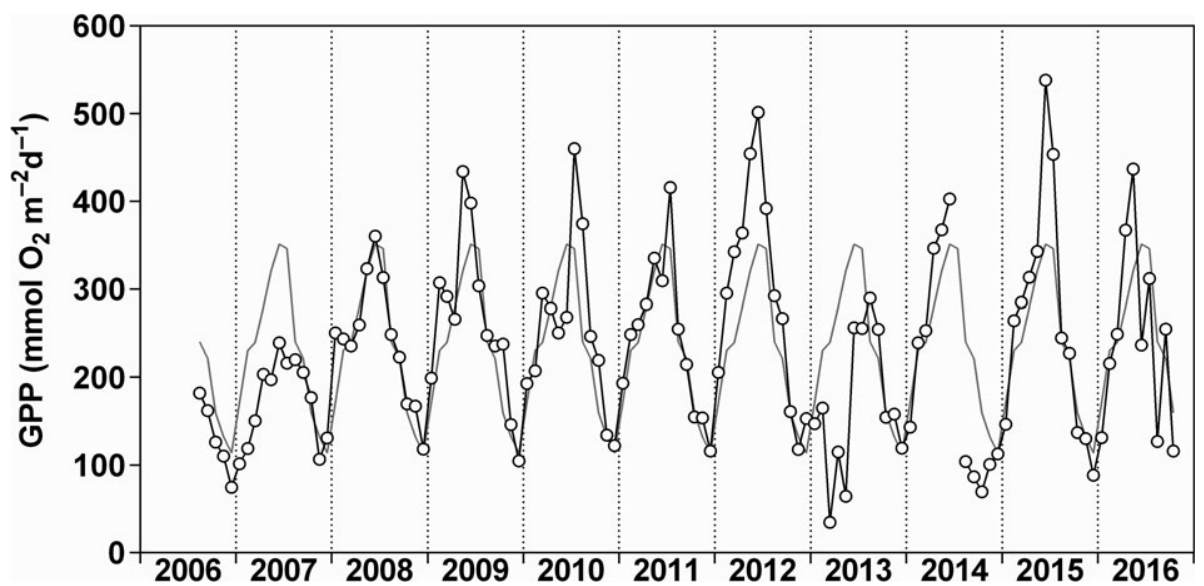

Fig. 1. Monthly community gross primary production (GPP in mmol $\mathrm{O}_{2} \mathrm{~m}^{-2} \mathrm{~d}^{-1}$ ) from August 2006 to October 2016 at $10 \mathrm{~m}$ depth over a $P$. oceanica meadow in the Bay of Revellata (Corsica). The gray line represents the climatological annual cycle of GPP for the 2006-2016 period, that was constructed from the average for each month computed from the values for that month from all of the years.

following the pattern expected from day-night cycle which was more marked during summer than during winter, and at $9.5 \mathrm{~m}$ than at the other two depths (Supporting Information Fig. S1). Since NCP and CR were tightly correlated to GPP (Supporting Information Fig. S2) and that GPP is the driver of NCP and CR in this type of marine environments (Duarte and Agustí 1998), hereafter, we will only investigate inter-annual variations of GPP.

Figure 1 shows the monthly means of GPP over a $10 \mathrm{yr}$ period from 2007 to 2016. There are marked seasonal variations of GPP with a maximum in June-July $\left(\sim 400 \mathrm{mmol} \mathrm{O}_{2} \mathrm{~m}^{-2} \mathrm{~d}^{-1}\right)$ and a minimum in November-December $\left(\sim 100 \mathrm{mmol} \mathrm{O}_{2} \mathrm{~m}^{-2} \mathrm{~d}^{-1}\right)$. These GPP patterns coincided with an oversaturation of $\mathrm{O}_{2}$ (107.0\% averaged for the whole data-set) in June-July and close to $\mathrm{O}_{2}$ saturation $(100.8 \%$ averaged for the whole dataset) in November-December (Supporting Information Fig. S1). The seasonal patterns and range of GPP values are consistent with those we derived at the same site and with the same method based on a shorter time-series (2006-2009) (Champenois and Borges 2012), as well as the data over a $P$. oceanica meadow in Magalluf Bay (Mallorca Island, Spain) based on $\mathrm{O}_{2}$ changes in benthic chambers (Barrón et al. 2006). Strong inter-annual variations were also observed with annual integrated GPP ranging from a minimum of $61.3 \mathrm{molO}_{2}$ $\mathrm{m}^{-2} \mathrm{yr}^{-1}$ in 2007 to a maximum of $107.6 \mathrm{molO}_{2} \mathrm{~m}^{-2} \mathrm{yr}^{-1}$ in 2012 (Table 1). Such inter-annual variations of GPP are consistent with the strong inter-annual variations of biometric variables over $P$. oceanica meadows, such as number of leaves, leaf biomass, leaf length reported at our and other studies sites in the Mediterranean Sea (Bay 1984; Pergent-Martini et al. 1994; Soullard et al. 1994; Gobert 2002; Guillén et al. 2013). The overall average of GPP over the $10 \mathrm{yr}$ period was $87.7 \pm 18.4 \mathrm{molO}_{2}$ $\mathrm{m}^{-2} \mathrm{yr}^{-1}$ (coefficient of variation [CV] of $21 \%$ ), close to average of measurements $(n=29)$ compiled by Duarte et al. (2010) over P. oceanica meadows (mainly in Spain and Greece) of
$67.1 \pm 11.1 \mathrm{molO}_{2} \mathrm{~m}^{-2} \mathrm{yr}^{-1}$ (based on an average of $0.25 \pm 0.04 \mathrm{mmol} \mathrm{O}_{2} \mathrm{~g}$ dry weight $(\mathrm{dw})^{-1} \mathrm{~d}^{-1}$ and an average biomass of $735 \mathrm{~g}_{\mathrm{dw}} \mathrm{m}^{-2}$ ). The values compiled by Duarte et al. (2010) were derived from several different sites and from different depths, and based on incubations with benthic chambers that can under-estimate GPP measurements due to photorespiration (Champenois and Borges 2012).

Differences from year-to-year were also apparent when comparing specific periods of the seasonal cycle of monthly GPP with the 10 yr climatology average (Fig. 1). The GPP averages for the period from September to January were repeatable from year-to-year, with the exception of 2007 and 2015. Shedding of older (and longer) P. oceanica leaves occurs in late summer and early fall that will be exported by fall-winter storms (Gobert et al. 2006). The leaves will start growing again in late winter (February). This has two consequences: first, GPP from $P$. oceanica collapses due to loss of biomass; second, light availability increases at the sediment surface and base of the

Table 1. Annual gross primary production (GPP in $\mathrm{molO}_{2} \mathrm{~m}^{-2} \mathrm{yr}^{-1}$ ) from 2007 to 2016 at $10 \mathrm{~m}$ depth over a $P$. oceanica meadow in the Bay of Revellata (Corsica), excluding year 2014 for which no measurements were available in July precluding annual integration.

\begin{tabular}{cc}
\hline Year & GPP $\left(\mathbf{m o l O}_{\mathbf{2}} \mathbf{~ m}^{-\mathbf{2}} \mathbf{y r}^{-\mathbf{1}}\right)$ \\
\hline 2007 & $61.3 \pm 0.6$ \\
2008 & $88.8 \pm 0.9$ \\
2009 & $96.0 \pm 1.0$ \\
2010 & $92.6 \pm 0.9$ \\
2011 & $89.9 \pm 0.9$ \\
2012 & $107.6 \pm 1.1$ \\
2013 & $61.9 \pm 0.6$ \\
2015 & $97.3 \pm 1.0$ \\
2016 & $80.0 \pm 0.8$ \\
Average & $87.7 \pm 2.6$ \\
\hline
\end{tabular}


shoots, allowing the growth of benthic and rhizome-epiphytic sciaphile flora, mainly red macro-algae such as Laurencia sp., Peyssonnnelia sp., Acrothamnion preissii, and Womersleyella setacea (Balata et al. 2007; Nesti et al. 2009). Champenois and Borges (2012) showed that the lack of fall storms during the exceptionally mild winter of 2006-2007 (Luterbacher et al. 2007) did not allow the export of dead P. oceanica leaves, blocking the development of benthic macro-algae, leading to a low GPP during this period. Similarly, in 2015, the first storms and export of dead leaves only occurred in early December, based on de visu observations during SCUBA dives. If we exclude years 2007 and 2015, then for the period of 2007-2016, the integrated GPP from September to January is $25.9 \pm 3.8 \mathrm{molO}_{2} \mathrm{~m}^{-2}(\mathrm{CV}=7.4 \%)$, corresponding to $29.7 \%$ of the annual GPP. This significant portion of annual GPP occurs when $P$. oceanica leaf biomass has been reported to be at its lowest (Gobert et al. 1995), and we hypothesize GPP is mainly sustained by sciaphile benthic red macro-algae, although this needs to be checked in future by direct measurements.

Inter-annual variations of annual GPP (Table 1) were due to variability during the other periods of the year, since the GPP values for the period from September to January were repeatable from year-to-year. In order to understand the source of variability we tested correlations of GPP with five other variables: SST, Chl $a$, SR, precipitation, and wind speed. These variables were chosen because high temperature $\left(>28^{\circ} \mathrm{C}\right)$ can lead to mortality of $P$. oceanica (Diaz-Almela et al. 2007; Marbà and Duarte 2012), but is also an important factor controlling metabolism (López-Urrutia et al. 2006); Chl $a$ and SR control light availability for photosynthesis of $P$. oceanica; Chl a might also indicate a contribution of the planktonic compartment to community GPP; precipitation can lead to inorganic nutrient inputs in near-shore marine areas that could be significant in the Mediterranean Sea (Koçak et al. 2010), and wind speed can provide information on vertical mixing and nutrient inputs as well as export of litter from the $P$. oceanica meadows. None of these variables correlated significantly with GPP for the period from September to January.

Maximum monthly SST were observed systematically in August, on average $24.2 \pm 0.8^{\circ} \mathrm{C}$ for the whole period, ranging between $23.2^{\circ} \mathrm{C}$ in 2007 and $25.5^{\circ} \mathrm{C}$ in 2012 (Fig. 2A). Minimum monthly SST were observed in February, on average $13.4 \pm 0.6^{\circ} \mathrm{C}$ for the whole period, ranging between $12.8^{\circ} \mathrm{C}$ in 2013 and $14.3^{\circ} \mathrm{C}$ in 2007 . The yearly maximum and minimum of monthly GPP were decoupled in time (May/June and November, respectively) from the maximum and minimum of SST (August and February, respectively). The warmest year with an annual average of $18.6^{\circ} \mathrm{C}$ in 2007 was also the year with the lowest GPP $\left(61.3 \mathrm{molO}_{2} \mathrm{~m}^{-2} \mathrm{yr}^{-1}\right)$, followed by 2012 $\left(18.5^{\circ} \mathrm{C}\right)$ that was the year with the highest GPP $\left(107.6 \mathrm{molO}_{2}\right.$ $\left.\mathrm{m}^{-2} \mathrm{yr}^{-1}\right)$. The coolest year with an annual average of $17.7^{\circ} \mathrm{C}$ in 2013 had a low GPP $\left(61.9 \mathrm{molO}_{2} \mathrm{~m}^{-2} \mathrm{yr}^{-1}\right)$, followed by $2010\left(17.8^{\circ} \mathrm{C}\right)$ with a GPP $\left(92.6 \mathrm{molO}_{2} \mathrm{~m}^{-2} \mathrm{yr}^{-1}\right)$ close to the overall average $\left(87.7 \mathrm{molO}_{2} \mathrm{~m}^{-2} \mathrm{yr}^{-1}\right)$. We conclude that year- to-year variability of annual SST was not the major factor controlling inter-annual variations of annual GPP.

In general, autumn and winter were the seasons with the highest precipitations (Fig. 2B). The cumulated annual precipitation was $649 \pm 138 \mathrm{~L} \mathrm{~m}^{-2}(\mathrm{CV}=23.8 \%)$ on average over the 2006-2016 period. The cumulated precipitation from September to March was $532 \pm 177 \mathrm{~L} \mathrm{~m}^{-2}$ on average over the 2006-2016 period, corresponding to $82.0 \%$ of the annual total. The driest period was from June to August, with a cumulated precipitation of $41 \pm 22 \mathrm{~L} \mathrm{~m}^{-2}$ on average over the 2006-2016 period, corresponding to $6.3 \%$ of the annual total. The rainiest year was 2010 (annual cumulated precipitation of $914 \mathrm{~L} \mathrm{~m}^{-2}$ ) with an annual GPP $\left(92.6 \mathrm{molO}_{2} \mathrm{~m}^{-2} \mathrm{yr}^{-1}\right)$ below the overall average. The driest year was 2007 (annual cumulated precipitation of $\left.444 \mathrm{~L} \mathrm{~m}^{-2}\right)$ with the lowest annual GPP $\left(61.3 \mathrm{molO}_{2}\right.$ $\left.\mathrm{m}^{-2} \mathrm{yr}^{-1}\right)$. During 2013, the cumulated annual precipitation was very close to the average over the 2006-2016 period $\left(685 \mathrm{~L} \mathrm{~m}^{-2}\right)$, although the annual GPP was among the lowest of the whole period $\left(61.9 \mathrm{molO}_{2} \mathrm{~m}^{-2} \mathrm{yr}^{-1}\right)$. No significant correlation was found between cumulated precipitation and the intensity of the spring phytoplankton bloom indicated by $\mathrm{Chl} a$ concentration. The Mediterranean Sea is very oligotrophic, so that nutrient inputs from wet atmospheric deposition can be significant (Koçak et al. 2010), and phytoplankton growth can respond at very short time-scales ( days) to nutrient pulses due to precipitation or wind (Thyssen et al. 2014). Nevertheless, over longer time scales (seasonal to inter-annual) precipitation did not seem to be a driver of GPP variability over P. oceanica meadows. This was also the case for wind speed that showed low seasonal and interannual variability. Average wind speed over the 2006-2016 period was $1.8 \pm 0.2 \mathrm{~m} \mathrm{~s}^{-1}(\mathrm{CV}=13.7 \%)$ (Fig. 2C). Wind speed was higher from September to March $\left(1.9 \pm 0.2 \mathrm{~m}^{-1}\right)$ than during the rest of the year $\left(1.6 \pm 0.1 \mathrm{~m} \mathrm{~s}^{-1}\right)$.

Cumulated annual SR averaged $2777 \pm 90 \mathrm{~h}(\mathrm{CV}=3.2 \%)$, over the 2006-2016 period. 2012 was the year with the highest SR $(2881 \mathrm{~h})$ and 2010 was the year with the lowest SR $(2606 \mathrm{~h})$. The period from May to September had a low variation in SR $(\mathrm{CV}=3.0 \%)$, while the period from January to April had a higher variation in SR $(C V=16.9 \%)$. Year 2010 had the highest GPP $\left(107.6 \mathrm{molO}_{2} \mathrm{~m}^{-2} \mathrm{yr}^{-1}\right)$ but a low SR $(2606 \mathrm{~h})$, while year 2012 had a GPP close to the overall average (92.6 $\left.\mathrm{molO}_{2} \mathrm{~m}^{-2} \mathrm{yr}^{-1}\right)$ although with the highest SR $(2881 \mathrm{~h})$. The yearly maximum of SR (July) did not coincide with the one of GPP (May-June), except for year 2010. The yearly minimum of SR (mostly in December) did not coincide with the one of GPP (mostly in November). Nevertheless, a significant positive linear relationship was found for the whole 2006-2016 period between monthly GPP and cumulated monthly SR $\left(r^{2}=0.38 ; p<0.0001 ; n=119\right)$ (Supporting Information Fig. S3), in agreement with previous findings on the role of light in regulating growth of $P$. oceanica meadows across time-scales from day-to-day (Gazeau et al. 2005) to seasonal (Alcoverro et al. 1995). Taken for each yearly cycle individually, the $r^{2}$ value of the linear correlation between GPP and SR ranged 

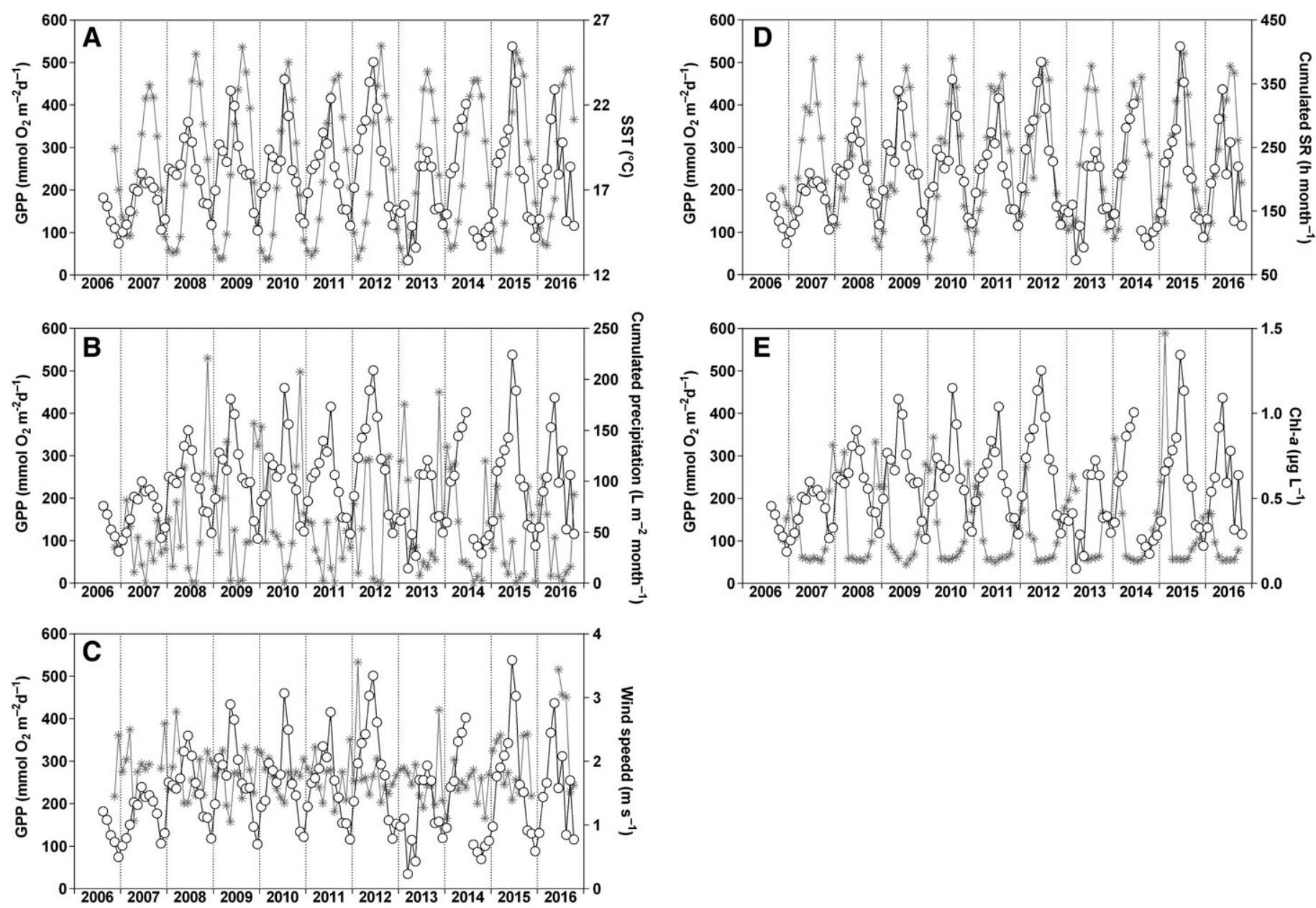

Fig. 2. Monthly community gross primary production (GPP in $\mathrm{mmol} \mathrm{O}_{2} \mathrm{~m}^{-2} \mathrm{~d}^{-1}$, open dots), sea surface temperature (SST in ${ }^{\circ} \mathrm{C}$, stars, A), cumulated precipitation $\left(\mathrm{L}^{-1} \mathrm{~m}^{-2}\right.$ month, stars, B), wind speed $\left(\mathrm{m} \mathrm{s}^{-1}\right.$, stars, C), cumulated solar radiation (SR in $\mathrm{h}$ month ${ }^{-1}$, stars, D), and chlorophyll $a$ concentration (Chl $a$ in $\mu \mathrm{g} \mathrm{L}^{-1}$, stars, E) from August 2006 to October 2016 at $10 \mathrm{~m}$ depth over a $P$. oceanica meadow in the Bay of Revellata (Corsica).

from 0.23 to 0.74 (Supporting Information Fig. S4), showing that additional processes also controlled seasonal and inter-annual variations of GPP, as discussed hereafter.

Chl $a$ values were low, in general below $1 \mu \mathrm{g} \mathrm{L}^{-1}$ (Fig. 2E). The timing and amplitude of the seasonal variations of the remoted sensed Chl $a$ data were in agreement with in situ measurements in the same area (Garrido et al. 2014). The average Chl a concentration was $0.3 \pm 0.2 \mu \mathrm{g} \mathrm{L}^{-1}$ $(\mathrm{CV}=72.0 \%)$ for the period 2006-2016. The seasonal maximum Chl $a$ concentration was observed in February-March corresponding to the spring diatom bloom (Garrido et al. 2014). During the spring bloom, the maximum monthly value was in March $2015\left(1.4 \mu \mathrm{g} \mathrm{L}^{-1}\right)$ and the minimum in March $2016\left(0.4 \mu \mathrm{g} \mathrm{L}^{-1}\right)$. In some years, an autumn Chl $a$ peak was also observed but lower than the corresponding spring peak. The lowest Chl $a$ concentrations were observed during the period from May to September, with an average of $0.14 \pm 0.01 \mu \mathrm{g} \mathrm{L}^{-1}(\mathrm{CV}=8.9 \%)$, typical in the study area due to nutrient depletion (Garrido et al. 2014). The yearly maximum of community GPP did not coincide with the spring phytoplankton blooms.

A PCA of the above mentioned variables allowed to summarize the variance across the whole data-set (Fig. 3). The first two principal components of variance (PC1 and PC2) described $69.6 \%$ of total variance. As GPP, SST, and SR all peaked in summer (Fig. 2A,D,E) they were positively related. Since Chl $a$ peaked in early spring during periods of low GPP and was very low during summer (period of high GPP) both variables were negatively related. Finally, GPP showed no relation to wind speed and a poor relation to precipitation.

In order to further explore inter-annual variations of GPP, SST, SR, Chl $a$, precipitation and wind speed, we computed the monthly anomalies (noted by') as the difference between each monthly value and the average value for that given month for the whole period (2006-2016), normalized by the average and expressed in \% (Fig. 4). The correlation analysis of the anomalies of variables did not show any significant relations across the entire data-set. In order to further examine 


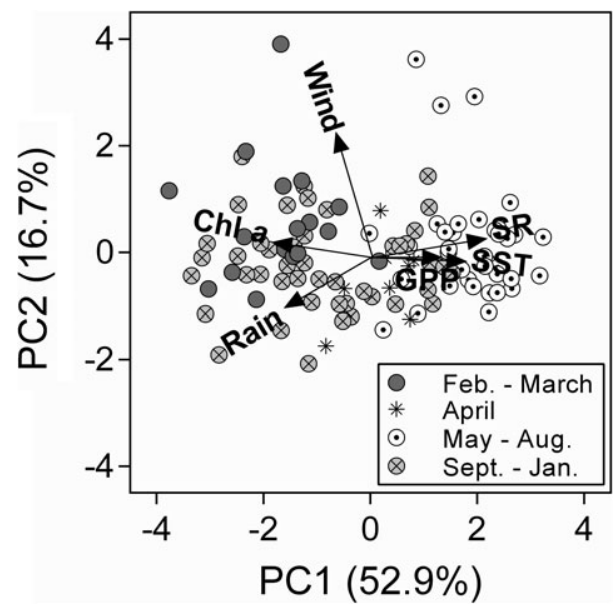

Fig. 3. Principal component analysis of monthly community gross primary production (GPP), sea surface temperature (SST), cumulated precipitation (rain), wind speed (wind), cumulated solar radiation (SR), and chlorophyll $a$ concentration ( $\mathrm{Chl} a$ ) from August 2006 to October 2016 at $10 \mathrm{~m}$ depth over a P. oceanica meadow in the Bay of Revellata (Corsica).

inter-annual variations, three different periods of the yearly cycle from February to August were investigated (the period from September to January was not examined since, as mentioned above, it was nearly repeatable from year to year). The first period corresponded to February and March, the second period was the month of April, and the third period was from May to August. These periods were chosen by separating the period from May to August, when Chl $a$ is systematically low, making this a coherent period. The month of April stands out as the month of the transition of winter-mixed conditions to spring/summer-thermally stratified conditions, when seasonally SST start to increase (Bay 1984). For any of these periods, there was no significant correlation between monthly anomalies of GPP (GPP') and those of cumulated precipitation and wind speed (not shown), so we will only examine hereafter the correlations with anomalies of SR $\left(\mathrm{SR}^{\prime}\right), \mathrm{SST}\left(\mathrm{SST}^{\prime}\right)$, and Chl $a\left(\right.$ Chl $\left.a^{\prime}\right)$.

For the first period (February and March), GPP was on average $13.9 \pm 4.1 \mathrm{molO}_{2} \mathrm{~m}^{-2}$ for the whole 2006-2016 period, corresponding to $16.1 \%$ of the annual total. We calculated a multiple linear regression (MLR) between the sum of GPP' for March and February as a function of the sum of cumulated SR $\left(\mathrm{SR}^{\prime}\right)$ and average Chl $a^{\prime}$ (data from year 2007 was excluded from the MLR as the lack of export of dead leaves led to abnormal GPP values):

$$
\begin{gathered}
\mathrm{GPP}^{\prime}=-6+0.0553 \times \mathrm{SR}^{\prime}+3.08 \times \mathrm{Chl} a^{\prime} \\
\left(r=0.87>r_{\operatorname{crit}(0.95, n=9)}=0.44\right)
\end{gathered}
$$

For the second period (month of April), GPP was on average $9.6 \pm 3.4 \mathrm{molO}_{2} \mathrm{~m}^{-2}$ for the whole $2006-2016$ period, corresponding to $11.1 \%$ of the annual total. This period is characterized by a very strong inter-annual variability in SR
$(\mathrm{CV}=17.6 \%)$, SST $(\mathrm{CV}=4.1 \%)$, and $\mathrm{Chl} a(\mathrm{CV}=74.4 \%)$ (Fig. 4A-C). Since this is the period of the year when SST starts to increase, we included SST' in addition to SR', Chl $a^{\prime}$ to compute the MLR for GPP' (excluding year 2013 for which remote sensed Chl $a$ were unavailable):

$$
\begin{aligned}
\mathrm{GPP}^{\prime}= & 29-0.061 \times \mathrm{SR}^{\prime}+4.33 \times \mathrm{Chl}^{\prime}-0.31 \times \mathrm{SST}^{\prime} \\
& \left(r=0.90>r_{\text {crit }(0.95, n=9)}=0.44\right)
\end{aligned}
$$

As for the first period (Eq. 3) a positive relation with Chl $a^{\prime}$ was observed although the relationship was negative with SR' unlike the first period.

For the third period (May-August), GPP was on average $38.7 \pm 8.2 \mathrm{molO}_{2} \mathrm{~m}^{-2}$ for the whole 2006-2016 period, corresponding to $41.1 \%$ of the annual total. This period was characterized by low Chl $a$ concentrations (Fig. 2E) and no clear relation was apparent between GPP' and Chl $a^{\prime}$ (Fig. 4C). However, there was a general positive variation of GPP' and SST' and SR' (Fig. 4A,B), so that a MLR was built with those variables (excluding year 2014 because GPP values were unavailable in July of that year due to malfunctioning of an oxymeter on the mooring):

$$
\begin{gathered}
\mathrm{GPP}^{\prime}=-287+0.052 \times \mathrm{SR}^{\prime}+11.93 \times \mathrm{SST}^{\prime} \\
\left(r=0.93>r_{\text {crit }}(0.95, n=9)=0.44\right)
\end{gathered}
$$

During the first (February and March) and second (month of April) periods, GPP' was positively related to Chl $a^{\prime}$. We previously showed that at seasonal time scales phytoplankton growth decreased community GPP by shading effect and reduced light availability for $P$. oceanica meadow rather than actually accounting for the planktonic contribution to community GPP (Champenois and Borges 2012). Indeed, we computed based on the GPP-Chl $a$ relation developed in the $P$. oceanica meadow of the Bay of Palma (Gazeau et al. 2005), that phytoplankton GPP was on average in February-April of $2.7 \mathrm{molO}_{2} \mathrm{~m}^{-2}$ corresponding to $11 \%$ of the measured community GPP of $25.1 \mathrm{molO}_{2} \mathrm{~m}^{-2}$ during the same period. From year-to-year, computed phytoplankton GPP in February-April ranged between $1.6 \mathrm{molO}_{2} \mathrm{~m}^{-2}$ in 2007 and $6.2 \mathrm{molO}_{2} \mathrm{~m}^{-2}$ in $2015(\mathrm{CV}=46 \%)$ and cannot account for the inter-annual variability of measured community GPP during the same period that ranged between $13.9 \mathrm{molO}_{2} \mathrm{~m}^{-2}$ in 2007 and 30.6 $\mathrm{molO}_{2} \mathrm{~m}^{-2}$ in $2009(\mathrm{CV}=21 \%)$. Alternatively, a common process could enhance both benthic and planktonic GPP leading to an indirect positive relation between $\mathrm{GPP}^{\prime}$ and $\mathrm{Chl} \mathrm{a}^{\prime}$. In the Bay of Revellata, inter-annual variations of phytoplankton growth are driven by inter-annual changes in dissolved inorganic nutrients, mainly due to weather conditions driving vertical mixing (Goffart et al. 2015). Enhanced dissolved inorganic nutrients inputs should lead to an increase of both planktonic and benthic GPP, and we hypothesize it could explain the GPP' and Chl $a^{\prime}$ relation. We also hypothesize 

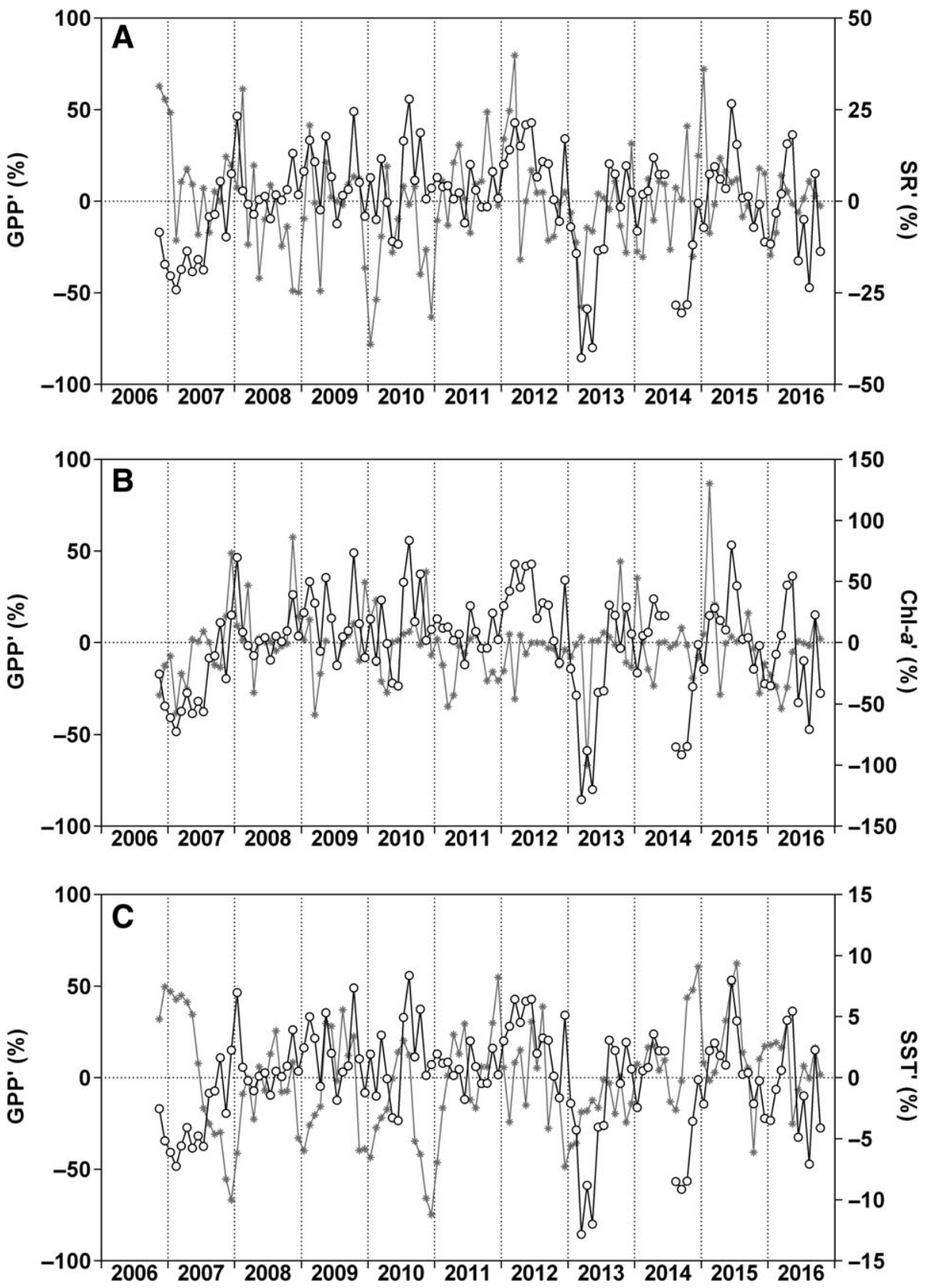

Fig. 4. Anomalies of monthly gross primary production (GPP' in $m m o l ~ O_{2} m^{-2} d^{-1}$, open dots), cumulated solar radiation ( $S R^{\prime}$ in $h$ month ${ }^{-1}$, stars, $\mathbf{A}$ ), chlorophyll $a$ concentration ( $\mathrm{Chl} a^{\prime}$ in $\mu \mathrm{g} \mathrm{L}^{-1}$, stars, B), and sea surface temperature (SST' in ${ }^{\circ} \mathrm{C}$, stars, C) from August 2006 to October 2016 at $10 \mathrm{~m}$ depth over a $P$. oceanica meadow in the Bay of Revellata (Corsica).

that an indirect relation to nutrient inputs might also explain the negative relation between GPP' and SST' and GPP' and SR' in April (second period, Eq. 4), as warm and sunny conditions during this month might indicate early stratification and less stormy weather leading to less nutrient inputs by mixing (Goffart et al. 2015). This might also explain why the month of April stood out in the analysis as a specific period, as this corresponds to transition period from a well-mixed winter regime to a more stratified spring regime (Bay 1984).
The positive relation between $\mathrm{GPP}^{\prime}$ and SST' during the third period (May-August) might reflect the enhancement of metabolic activity (Arrhenius temperature dependence relation, for example López-Urrutia et al. 2006). Alternatively it could indirectly reflect sunnier weather. Indeed, a positive relationship was found between GPP' and SR' during the first (February and March, Eq. 1) and third (May-August, Eq. 5) periods, in agreement with previous studies that have shown that light availability is the major process controlling growth and 


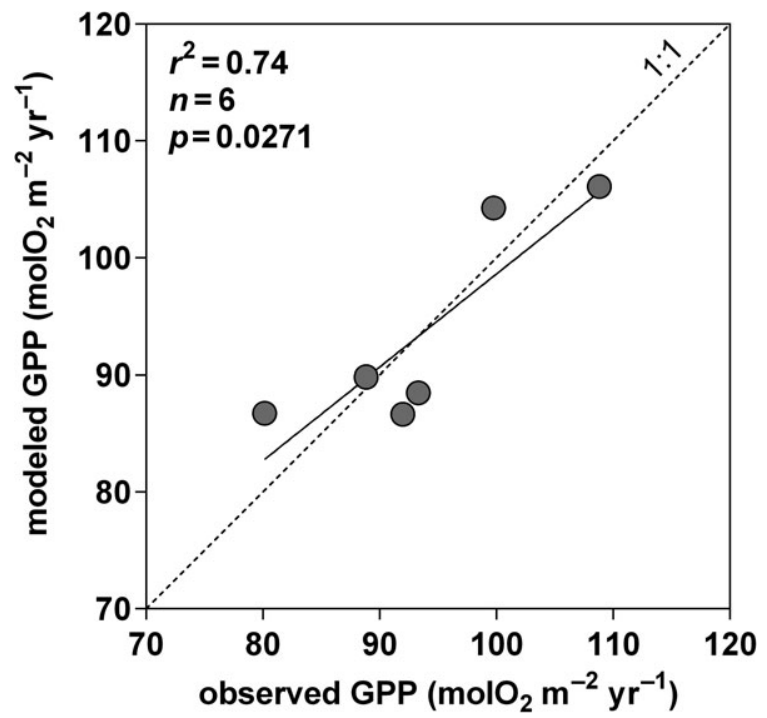

Fig. 5. Annual modeled and observed gross primary production (GPP in $\mathrm{molO}_{2} \mathrm{~m}^{-2} \mathrm{yr}^{-1}$ ) from 2007 to 2016 at $10 \mathrm{~m}$ depth over a $P$. oceanica meadow in the Bay of Revellata (Corsica), excluding years 2007, 2013, and 2015. Solid line corresponds to the linear regression, dotted line corresponds to 1:1 line.

GPP of P. oceanica both in time (seasonally) (Alcoverro et al. 1995) and in space (with depth) (Pergent-Martini et al. 1994).

We modeled GPP combining Eqs. 3-5 for their respective periods and using a constant GPP for the period from September to January $\left(25.9 \mathrm{molO}_{2} \mathrm{~m}^{-2}\right.$, corresponding to cumulated value averaged for the whole 2006-2016 period), excluding the $2 \mathrm{yr}$ when fall storms did not export litter leading to abnormal GPP values (2007 and 2015) and excluding years 2013 (no Chl $a$ data in April) and 2014 (no GPP data in July). The modeled and observed annual GPP (Fig. 5) were significantly linearly correlated $\left(r=0.86>r_{\text {crit }(0.95, n=6)}=0.71\right)$, with a slope $(0.797)$ not significantly different from $1\left(t=0.870<t_{\text {crit }(0.95, n=6)}=2.78\right.$, $p=0.43)$, and a $y$-intercept (18.95) not significantly different from $0\left(t=0.860<t_{\text {crit }}(0.95, n=6)=2.78, p=0.44\right)$. The statistical model allowed to explain $74 \%$ of the inter-annual variability of GPP of P.oceanica meadow in our study site.

Possible future evolution of GPP in P. oceanica meadows in response to warming and changes in occurrence of winter storms

GPP from September to January was $17.5 \mathrm{molO}_{2} \mathrm{~m}^{-2}$ and $15.2 \mathrm{molO}_{2} \mathrm{~m}^{-2}$ in 2007 and 2015, respectively, due to the absence autumn storms and export of fallen leaf litter (observed de visu during the scuba dives) that we hypothesize did not allow development of benthic sciaphile flora by occultation of light. GPP during the other years averaged 25.9 $\mathrm{molO}_{2} \mathrm{~m}^{-2}$ for the same period. By difference, the putative GPP of benthic sciaphile flora can be estimated to 9-10 $\mathrm{molO}_{2}$ $\mathrm{m}^{-2}$ (or $\sim 67 \mathrm{mmol} \mathrm{O}_{2} \mathrm{~m}^{-2} \mathrm{~d}^{-1}$ ), corresponding to $10 \%$ of the annual GPP of the meadow. The GPP of benthic sciaphile flora was estimated indirectly and is probably over-estimated as accumulation of litter might have also decreased by occultation GPP of $P$. oceanica, and requires to be confirmed in future by direct measurements. Climatic models predict a decrease of autumn-winter storms in the Mediterranean Sea region, possibly related to an increase of the North Atlantic Oscillation (NAO) index (for example Giorgi and Lionello 2008). This is related to a stronger dominance of anti-cyclonic conditions over the Mediterranean Sea region in future, so that depressions coming from the Atlantic Ocean would be deviated further north. This might lead in future to changes of GPP seasonality and of annual NCP, due to a more systematic accumulation of leaf litter within the meadow during winter instead of export as presently observed (Champenois and Borges 2012).

A warming of surface waters is predicted for the NorthWest Mediterranean Sea of $\sim 2^{\circ} \mathrm{C}$ in winter and $\sim 3^{\circ} \mathrm{C}$ in summer for 2071/2110 compared to 1961/1990 (Giorgi and Lionello 2008; Mariotti et al. 2010; Adloff et al. 2015). This prediction is in line with the observed increase of annual

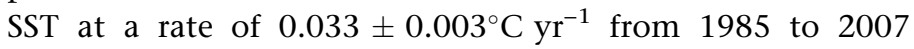
reported by Garcia and Belmonte (2011). P. oceanica survives within a temperature range between $9^{\circ} \mathrm{C}$ and $29^{\circ} \mathrm{C}$, but the
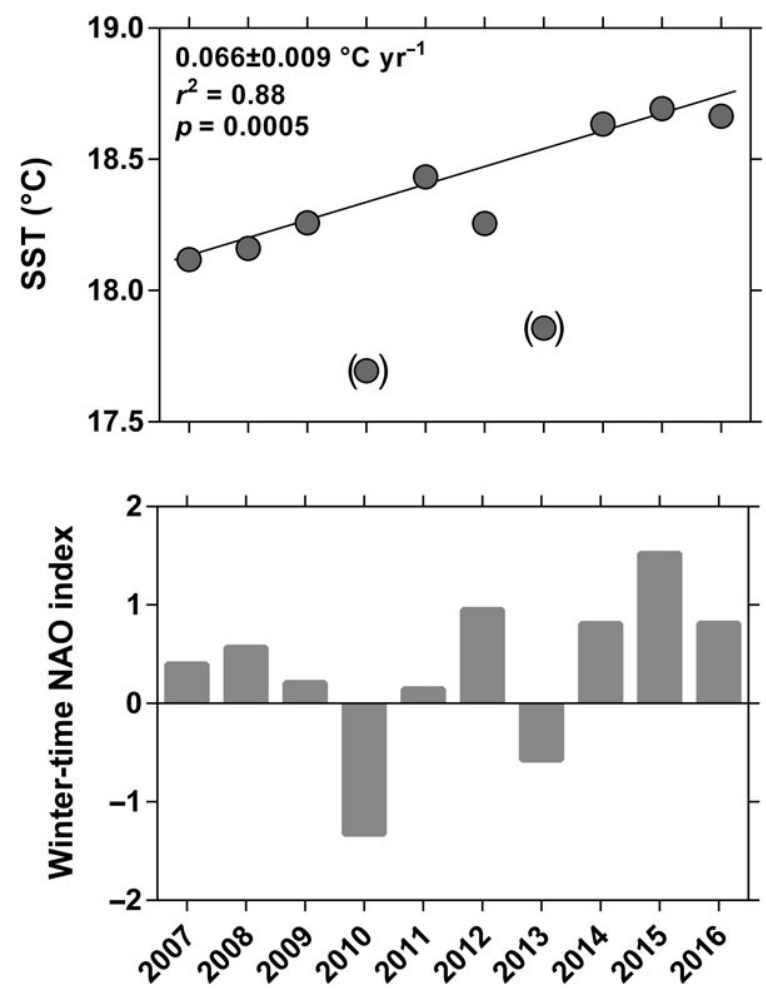

Fig. 6. Annual average of sea surface temperature (SST in ${ }^{\circ} \mathrm{C}$ ) and the North Atlantic Oscillation (NAO) index averaged for January-March (from National Oceanic and Atmospheric Administration Climate Prediction Center). Solid line corresponds to the linear regression excluding the 2 yrs with a negative NAO index (2010 and 2013) indicated by brackets. 

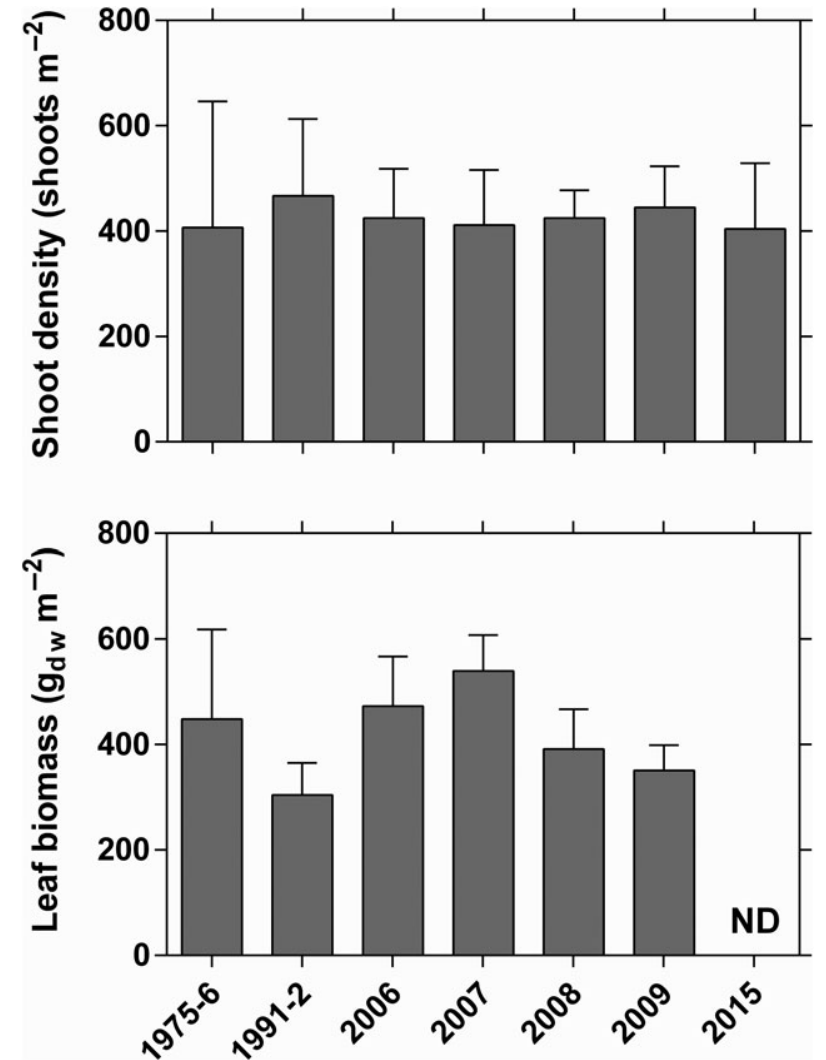

Fig. 7. Shoot density (shoots $\mathrm{m}^{-2}$ ) and leaf biomass (g dry weight [dw] $\mathrm{m}^{-2}$ ) of $P$. oceanica at $10 \mathrm{~m}$ depth in the Bay of Revellata. Data from 1975 to 1976 are from Bay (1984) and data from 1991 to 1992 are from Gobert et al. (1995). Shoot density was not statistically different between years at 0.05 level (one-way ANOVA: $f=0.294, p=0.938$ ). Leaf biomass was statistically different between years (one-way ANOVA: $f=8.191$, $p<0.001$, respectively), but no there was no clear trend in time (decrease or increase).

optimum conditions are within $17^{\circ} \mathrm{C}$ and $20^{\circ} \mathrm{C}$ (Boudouresque and Meinesz 1982). For the period 2006-2016, May and June were the 2 months with average temperatures closest to optimum conditions, respectively $17.1 \pm 0.9$ and $20.1 \pm 1.4^{\circ} \mathrm{C}$. These 2 months have a high SR with a value cumulated over the 2 months of $634 \mathrm{~h}$. Due to the combination of favorable light and temperature conditions, these 2 months have a high GPP value, respectively, the third $\left(9.9 \mathrm{molO}_{2} \mathrm{~m}^{-2}\right.$ month $\left.^{-1}\right)$ and second $\left(10.5 \mathrm{molO}_{2}\right.$ $\mathrm{m}^{-2}$ month $^{-1}$ ) most productive of the year. The month of July is the most productive one $\left(10.7 \mathrm{molO}_{2} \mathrm{~m}^{-2} \mathrm{month}^{-1}\right)$, with an average SST of $22.9^{\circ} \mathrm{C}$, above the optimum temperature but well below to maximum survival temperature $\left(28^{\circ} \mathrm{C}\right)$, and within the temperature comfort range, between $13^{\circ} \mathrm{C}$ and $24^{\circ} \mathrm{C}$ (Boudouresque and Meinesz 1982). With a projected increase of $3^{\circ} \mathrm{C}$ for the end of the century in the Mediterranean, the months of optimum temperature for P. oceanica would shift by 1 month from May-June to AprilMay that had a cumulated SR of $539 \mathrm{~h}$ during the period 2006-2016. This would then mean that with future projected warming there would be a loss of $15 \%$ of incoming SR for the months of the year within the optimum temperature growth conditions for $P$. oceanica. The loss of incoming SR could to some extent be compensated by a decrease of projected cloudiness (Navarra and Tubiana 2013), although modeling of cloudiness is notoriously difficult and uncertain.

During the decade of measurements of daily SST $(n=3317)$, we recorded 272 events with daily average temperatures above $24^{\circ} \mathrm{C}(8.2 \%$ of the time), with an overall maximum value of $27.9^{\circ} \mathrm{C}$. Over that period, annual GPP did not show any significant temporal trend (increase or decrease), although a very marked warming trend of $0.066^{\circ} \mathrm{C} \mathrm{yr}^{-1}$ was recorded at our study site during that time period (Fig. 6). This value is almost five times higher than the global average warming over the last $50 \mathrm{yr}$ of $0.013^{\circ} \mathrm{C} \mathrm{yr}^{-1}$ (IPCC 2013). Such abnormally strong warming is probably transient and coincided with a period of sustained positive winter-time NAO index (Fig. 6). Note that the 2 yr with negative winter-time NAO index values were the coolest of the whole period and deviated from the general trend (Fig. 6). Despite this warming, the fact that the shoot density and leaf biomass in this meadow remain stable (Fig. 7) is consistent with the fact that we did not record events of daily temperature above the threshold temperature $\left(28^{\circ} \mathrm{C}\right)$ at which $P$. oceanica shoot mortality starts occurring (Diaz-Almela et al. 2007), and that the meadow is less than $10 \%$ of the time above the limit of the temperature comfort zone for $P$. oceanica. With a projected increase of $3^{\circ} \mathrm{C}$ in the Mediterranean Sea at the end of the century, the average temperatures for July-September would be $26-27^{\circ} \mathrm{C}$, meaning that the meadow would experience 3 months per year with temperatures above the $P$. oceanica comfort range, and the occurrence of events with SST $>28^{\circ} \mathrm{C}$ would also be expected to increase. Furthermore, very warm events in the Mediterranean are favorable for the development of filamentous algae (Ceramium sp., Antithamnion sp.), as observed in 2003 and 2007 in the Parc National de Port-Cros (France) (Perez 2008). A relatively large fraction of GPP in July and August are due to epiphytic filamentous macroalgae (Champenois and Borges 2012) dominated by the Ceramiales group (Jacquemart and Demoulin 2008) that compete with the host plant (P. oceanica) for nutrients and light. The projected warming would possibly lead to an earlier development of filamentous epiphytic algae during the year, and increase competition with $P$. oceanica for resources. Altogether, these effects are expected to lead to a future decrease of GPP in $P$. oceanica meadows even in those that are near-pristine as the one we studied.

Here, we describe for the first-time the inter-annual variations of GPP in a seagrass ecosystem based on a continuous record spanning $10 \mathrm{yr}$. We found that annual GPP in a $P$. oceanica meadow in Corsica was surprisingly variable from year to year, with extreme maximum (107.6 $\left.\mathrm{molO}_{2} \mathrm{~m}^{-2} \mathrm{yr}^{-1}\right)$ and minimum $\left(61.3 \mathrm{molO}_{2} \mathrm{~m}^{-2} \mathrm{yr}^{-1}\right)$ values differing by a factor of 1.76. We explored the drivers of this strong inter-annual 
variability in P. oceanica GPP. It is well established from previous studies that seasonal and spatial variations of productivity of $P$. oceanica depend on light, and this could indeed explain part of the observed inter-annual variations. No significant long-term change (decline or increase) of GPP could be observed in our data-set, despite the fact that a sustained warming was observed in the study area at a rate that was five times higher than the global average warming over the last $50 \mathrm{yr}$, probably related to a period of prolonged positive NAO anomaly. Long-term changes in shoot density and leaf biomass of $P$. oceanica were not detected in comparison to $1970 \mathrm{~s}$ and 1990s. Overall, this indicates that the studied meadow is still within the temperature comfort zone of $P$. oceanica, although this is based on the study of Boudouresque and Meinesz (1982) that should be updated by new investigations of temperature tolerance, as it might have changed over the last decades by adaptation to warming conditions, and is variable among different ecotypes (Marín-Guirao et al. 2016). Consequently, the studied meadow is expected to respond in future to further warming, that should warrant continued monitoring of GPP that can be achieved relatively easily with moored oxygen sensors, as shown here. While $P$. oceanica productivity does not seem to respond significantly to expected changes in $\mathrm{pH}$ conditions (ocean acidification) (Cox et al. 2016), strong future changes are expected from changes in light availability notably as a consequence of eutrophication. Indeed, even in a pristine site such as the Bay of Revellata, GPP strongly responded to inter-annual variations of light availability, so that sustained periods of decreasing light conditions as expected in more eutrophied sites are expected to strongly impact $P$. oceanica productivity.

\section{References}

Abadie, A., S. Gobert, M. Bonacorsi, P. Lejeune, G. Pergent, and C. Pergent-Martini. 2015. Marine space ecology and seagrasses. Does patch type matter in Posidonia oceanica seascapes? Ecol. Indic. 57: 435-446. doi:10.1016/j.ecolind.2015.05.020

Abadie, A., P. Lejeune, G. Pergent, and S. Gobert. 2016. From mechanical to chemical impact of anchoring in seagrasses: The premises of anthropogenic patch generation in Posidonia oceanica meadows. Mar. Pollut. Bull. 109: 61-71. doi: 10.1016/j.marpolbul.2016.06.022

Adloff, F., and others. 2015. Mediterranean Sea response to climate change in an ensemble of twenty first century scenarios. Clim. Dyn. 45: 2775 -2802, DOI: 10.1007/s00382-015-2507-3

Alcoverro, T., C. M. Duarte, and J. Romero. 1995. Annual growth dynamics of Posidonia oceanica: Contribution of large-scale versus local factors to seasonality. Mar. Ecol. Prog. Ser. 120: 203-210. doi:10.3354/meps120203

Apostolaki, E. T., M. Holmer, N. Marbà, and I. Karakassis. 2010. Metabolic imbalance in coastal vegetated (Posidonia oceanica) and unvegetated benthic ecosystems. Ecosystems 13: 459-471. doi:10.1007/s10021-010-9330-9
Balata, D., U. Nesti, L. Piazzi, and F. Cinelli. 2007. Patterns of spatial variability of seagrass epiphytes in the north-west Mediterranean Sea. Mar. Biol. 151: 2025-2035. doi: 10.1007/s00227-006-0559-y

Barrón, C., C. M. Duarte, M. Frankignoulle, and A. V. Borges. 2006. Organic carbon metabolism and carbonate dynamics in a Mediterranean seagrass (Posidonia oceanica) meadow. Estuaries Coast. 29: 417-426. doi:10.1007/ BF02784990

Bay, D. 1984. A field study of the growth dynamics and productivity of Posidonia oceanica (L.) Delile in Calvi Bay, Corsica. Aquat. Bot. 20: 43-64. doi:10.1016/ 0304-3770(84)90026-3

Bethoux, J. P., and G. Copin-Montégut. 1986. Biological fixation of atmospheric nitrogen in the Mediterranean Sea. Limnol. Oceanogr. 31: 1353-1358. doi:10.4319/lo.1986.31.6.1353

Bonacorsi, M., C. Pergent-Martini, N. Bréand, and G. Pergent. 2013. Is Posidonia oceanica regression a general feature in the Mediterranean Sea? Mediterr. Mar. Sci. 14: 193-203. doi:10.12681/mms.334.

Boudouresque, C. F., and A. Meinesz. 1982. Découverte de l'herbier de Posidonie. Parc National de Port-Cros Cahier 4: 1-79.

Boudouresque, C. F., and others. 2006. Préservation et conservation des herbiers à Posidonia oceanica. Ramonge Publisher: $1-20$.

Boudouresque, C. F., G. Bernard, G. Pergent, A. Shili, and M. Verlaque. 2009. Regression of Mediterranean seagrasses caused by natural processes and anthropogenic disturbances and stress: A critical review. Bot. Mar. 52: 395-418.

Campagne, C. S., J.-M. Salles, P. Boissery, and J. Deter. 2015. The seagrass Posidonia oceanica: Ecosystem services identification and economic evaluation of good benefits. Mar. Pollut. Bull. 97: 391-400. doi:10.1016/j.marpolbul.2015.05.061

Carr, J., P. D'Odorico, K. McGlathery, and P. Wiberg. 2010. Stability and bistability of seagrass ecosystems in shallow coastal lagoons: Role of feedbacks with sediment resuspension and light attenuation. J. Geophys. Res. 115: G03011. doi:10.1029/2009JG001103

Champenois, W., and A. V. Borges. 2012. Seasonal and interannual variations of community metabolism rates of a Posidonia oceanica seagrass meadow. Limnol. Oceanogr. 57: 347-361. doi:10.4319/lo.2012.57.1.0347

Costanza, R., and others. 1997. The value of the world's ecosystem services and natural capital. Nature 387: 253 -260, DOI: $10.1038 / 387253 a 0$

Cox, T. E., F. Gazeau, S. Alliouane, I. E. Hendriks, P. Mahacek, A. Le Fur, and J.-P. Gattuso. 2016. Effects of in situ $\mathrm{CO}_{2}$ enrichment on structural characteristics, photosynthesis, 1 and growth of the Mediterranean seagrass Posidonia oceanica. Biogeosciences 13: 2179-2194. doi: 10.5194/bg-13-2179-2016

Dauby, P., and others. 1995. Particle fluxes over a Mediterranean seagrass bed: A one year case study. Mar. Ecol. Prog. Ser. 126: 233 -246, DOI: 10.3354/meps126233 
Diaz-Almela, E., N. Marba, and C. M. Duarte. 2007. Consequences of Mediterranean warming events in seagrass (Posidonia oceanica) flowering records. Glob. Chang. Biol. 13: 224-235. doi:10.1111/j.1365-2486.2006.01260.x

Duarte, C. M. 2002. The future of seagrass meadows. Environ. Conserv. 29: 192-206.

Duarte, C. M., and S. Agustí. 1998. The CO2 balance of unproductive aquatic ecosystems. Science 281: 234-236. doi: 10.1126/science.281.5374.234

Duarte, C. M., and C. L. Chiscano. 1999. Seagrass biomass and production: A reassessement. Aquat. Bot. 65: 159-174. doi: 10.1016/S0304-3770(99)00038-8

Duarte, C. M., J. J. Middelburg, and N. Caraco. 2005. Major role of marine vegetation on the oceanic carbon cycle. Biogeosciences 2: 1-8. doi:10.5194/bg-2-1-2005

Duarte, C. M., N. Marbà, E. Gacia, J. W. Fourqurean, J. Beggins, C. Barrón, and E. T. Apostolaki. 2010. Seagrass community metabolism: Assessing the carbon sink capacity of seagrass meadows. Global Biogeochem. Cycles 24: GB4032. doi:10.1029/2010GB003793

Fourqurean, J. W., and others. 2012. Seagrass ecosystems as a globally significant carbon stock. Nat. Geosci. 5: 505 -509, DOI: $10.1038 /$ ngeo1477

Frankignoulle, M., and J.-M. Bouquegneau. 1987. Seasonal variations of the diel carbon budget of a marine macrophytes ecosystem. Mar. Ecol. Prog. Ser. 38: 197-199. doi:10.3354/ meps038197

Gacia, E., and C. M. Duarte. 2001. Sediment retention by a Mediterranean Posidonia oceanica meadow: The balance between deposition and resuspension. Estuar. Coast. Shelf Sci. 52: 505-514. doi:10.1006/ecss.2000.0753

García, M. J. L., and A. M. C. Belmonte. 2011. Recent trends of SST in the Western Mediterranean basins from AVHRR Pathfinder data (1985-2007). Glob. Planet. Change 78: 127-136. doi:10.1016/j.gloplacha.2011.06.001

Garrido, M., and others. 2014. Contrasting patterns of phytoplankton assemblages in two coastal ecosystems in relation to environmental factors (Corsica, NW Mediterranean Sea). Diversity 6: 296 -322, DOI: 10.3390/d6020296

Gazeau, F., and others. 2005. Whole-system metabolism and $\mathrm{CO}_{2}$ fluxes in a Mediterranean Bay dominated by seagrass beds (Palma Bay, NW Mediterranean). Biogeosciences 2: 43 -60, DOI: $10.5194 / \mathrm{bg}-2-43-2005$

Giorgi, F., and P. Lionello. 2008. Climate change projections for the Mediterranean region. Glob. Planet. Change 63: 90-104. doi:10.1016/j.gloplacha.2007.09.005

Gobert S. 2002. Variations spatiale et temporelle de l'herbier à Posidonia oceanica (L.) Delile, 207 pp. Ph.D. thesis. Univ. of Liège, Belgium.

Gobert, S., S. Belkhiria, P. Dauby, S. Havelange, M. Soullard, and J.-M. Bouquegneau. 1995. Variations temporelles de la phénologie et de la composition biochimique de la phanérogame marine Posidonia oceanica en baie de Calvi. Bull. Soc. R. Sci. Liège 64: 263-284.
Gobert, S., and others. 2006, p. 387 -408. In A. W. D. Larkum, R. J. Orth, and C. M. Duarte [eds.], Biology of Posidonia. Seagrasses: Biology, ecology and conservation: Springer.

Goffart, A., J.-H. Hecq, and L. Legendre. 2015. Drivers of the winter-spring phytoplankton bloom in a pristine NW Mediterranean site, the Bay of Calvi (Corsica): A long-term study (1979-2011). Prog. Oceanogr. 137: 121-139. doi: 10.1016/j.pocean.2015.05.027

Gonzalez-Correa, J. M., J. T. Bayle-Sempere, J. L. SanchezLizaso, C. Valle, P. Sanchez-Jerez, and J. M. Ruiz. 2005. Recovery of deep Posidonia oceanica meadows degraded by trawling. J. Exp. Mar. Bio. Ecol. 320: 65-76. doi:10.1016/j. jembe.2004.12.032

Guala, I., S. Simeone, M. C. Buia, S. Flagella, M. Baroli, and G. De Falco. 2006. Posidonia oceanica 'banquette' removal: Environmental impact and management implications. Biol. Mar. Mediterr. 13: 149-153.

Guillén, J. E., and others. 2013. Evolution of Posidonia oceanica seagrass meadows and its implications for management. J. Sea Res. 83: 65 -71, DOI: 10.1016/j.seares.2013.04.012

Ho, D. T., C. S. Law, M. J. Smith, P. Schlosser, M. Harvey, and P. Hill. 2006. Measurements of air-sea gas exchange at high wind speeds in the Southern Ocean: Implications for global parameterizations. Geophys. Res. Lett. 33: L16611. doi: 10.1029/2006GL026817

Holmer, M., and E. Kristensen. 1992. Impact of marine fish cage farming on metabolism and sulfate reduction of underlying sediments. Mar. Ecol. Prog. Ser. 80: 191-201. doi:10.3354/meps080191

Holmer, M., C. M. Duarte, and N. Marbà. 2003. Sulfur cycling and seagrass (Posidonia oceanica) status in carbonate sediments. Biogeochemistry 66: 223-239. doi:10.1023/B: BIOG.0000005326.35071.51

Holmer, M., and M. S. Frederiksen. 2007. Stimulation of sulfate reduction rates in Mediterranean fish farm sediments inhabited by the seagrass Posidonia oceanica. Biogeochemistry 85: 169-184. doi:10.1007/s10533-007-9127-x

IPCC 2013. Climate Change 2013: The Physical Science Basis. Contribution of Working Group I to the Fifth Assessment Report of the Intergovernmental Panel on Climate Change In Stocker, T. F., D. Qin, G.-K. Plattner, M. Tignor, S.K. Allen, J. Boschung, A. Nauels, Y. Xia, V. Bex and P.M. Midgley [eds.]. Cambridge University Press, Cambridge, United Kingdom and New York, NY, USA, 1535 pp. doi:10.1017/CBO9781107415324

Jacquemart, J., and V. Demoulin. 2008. Comparison of the epiphytic macroflora of Posidonia oceanica leaves in different meadows of the western Mediterranean. Flora Mediterranea 18: 393-420.

Jentsch, A., J. Kreyling, and C. Beierkuhnlein. 2007. A new generation of climate-change experiments: Events, not trends. Front. Ecol. Environ. 5: 1. doi:10.1890/060097

Johnson, H. K. 1999. Simple expressions for correcting wind speed data for elevation coastal. Ecol. Model. 88: 101-112. https://doi.org/10.1016/S0378-3839(99)00016-2 
Jordà, G., N. Marbà, and C. M. Duarte. 2012. Mediterranean seagrass vulnerable to regional climate warming. Nat. Clim. Chang. 2: 821-882. doi:10.1038/nclimate1533

Kennedy, H., J. Beggins, C. M. Duarte, J. W. Fourqurean, M. Holmer, N. Marbà, and J. J. Middelburg. 2010. Seagrass sediments as a global carbon sink: Isotopic constraints. Global Biogeochem. Cycles 24: GB4026. doi:10.1029/2010GB003848

Koçak, N., N. Kubilay, S. Tugrul, and N. Mihalopoulos. 2010. Atmospheric nutrient inputs to the northern Levantine basin from a long-term observation: Sources and comparison with riverine inputs. Biogeosciences 7: 4037-4050. doi: 10.5194/bg-7-4037-2010

Kwiatkowska, E. J., B. A. Franz, G. Meister, C. R. McClain, and X. Xiong. 2008. Cross-calibration of ocean color bands from moderate resolution imaging spectroradiometer on Terra platform. Appl. Opt. 47: 6796-6810. doi:10.1364/ AO.47.006796

La Rosa, T., S. Mirto, A. Mazzola, and R. Danovaro. 2001. Differential responses of benthic microbes and meiofauna to fish-farm disturbance in coastal sediments. Environ. Pollut. 112: 427-434. doi:10.1016/S0269-7491(00)00141-X

López-Urrutia, A., E. San Martin, R. P. Harris, and X. Irigoien. 2006. Scaling the metabolic balance of the oceans. Proc. Natl. Acad. Sci. USA 103: 8739-8744. doi:10.1073/pnas.0601137103

Luterbacher, J., M. A. Liniger, A. Menzel, N. Estrella, M. DellaMarta, C. Pfister, T. Rutishauser, and E. Xoplaki. 2007. Exceptional European warmth of autumn 2006 and winter 2007: Historical context, the underlying dynamics, and its phenological impacts. Geophys. Res. Lett. 34: L12704. doi:10.1029/2007GL029951

Marbà, N., and C. M. Duarte. 2010. Mediterranean warming triggers seagrass (Posidonia oceanica) shoot mortality. Glob. Chang. Biol. 16: 2366-2375. https://doi.org/10.1111/j. 1365-2486.2009.02130.x.

Marbà, N., E. Díaz-Almela, and C. M. Duarte. 2014. Mediterranean seagrass (Posidonia oceanica) loss between 1842 and 2009. Biol. Conserv. 176: 183-190. doi:10.1016/j.biocon.2014.05.024

Marín-Guirao, L., J. M. Ruiz, E. Dattolo, R. Garcia-Munoz, and G. Procaccini. 2016. Physiological and molecular evidence of differential short-term heat tolerance in Mediterranean seagrasses. Sci. Rep. 6: 28615. doi:10.1038/srep28615

Mariotti, A., Y. Pan, N. Zeng, and A. Alessandri. 2015. Longterm climate change in the Mediterranean region in the midst of decadal variability. Clim. Dyn. 44: 1437-1456. doi:10.1007/s00382-015-2487-3

Mateo, M. Á., J. Romero, M. Pérez, M. M. Littler, and D. S. Littler. 1997. Dynamics of millenary organic deposits resulting from the growth of the Mediterranean seagrass Posidonia oceanica. Estuar. Coast. Shelf Sci. 44: 103-110. doi:10.1006/ecss.1996.0116

Mateo, M.-Á., J.-L. Sánchez-Lizaso, and J. Romero. 2003. Posidonia oceanica 'banquettes': A preliminary assessment of the relevance for meadow carbon and nutrients budget. Estuar.
Coast. Shelf Sci. 56: 85-90. doi:10.1016/S0272-7714(02) 00123-3

Mateo, M. A., J. Cebrián, K. Dunton, and T. Mutchler. 2006. Carbon flux in seagrass ecosystems, p. 159-192. In A. W. D. Larkum, R. J. Orth, and C. M. Duarte [eds.], Seagrasses: Biology, ecology and conservation. Springer.

Meinesz, A., S. Cirik, B. Akcali, F. Javel, M. Migliaccio, T. Thibaut, A. Yüksek, and G. Procaccini. 2009. Posidonia oceanica in the Marmara Sea. Aquat. Bot. 90: 18-22. doi: 10.1016/j.aquabot.2008.04.013

Meister, G., B. A. Franz, E. J. Kwiatkowska, and C. R. McClain. 2012. Corrections to the calibration of MODIS aqua ocean color bands derived from SeaWiFS data. IEEE Trans. Geosci. Remote Sens. 50: 310-319. doi:10.1109/IGARSS.2010.5651742

Mirto, S., C. Arigò, L. Genovese, A. Pusceddu, C. Gambi, and R. Danovaro. 2014. Nematode assemblage response to fishfarm impact in vegetated (Posidonia oceanica) and nonvegetated habitats aquaculture. Environ. Interact. 5: 17-28. doi:10.3354/aei00091

Navarra, A., and L. Tubiana [eds.]. 2013. Regional assessment of climate change in the Mediterranean. Volume 1: Air, sea and precipitation and water. Springer.

Nesti, U., L. Piazza, and D. Balata. 2009. Variability in the structure of epiphytic assemblages of the Mediterranean seagrass Posidonia oceanica in relation to depth. Mar. Ecol. 30: 276-287. doi:10.1111/j.1439-0485.2008. 00275.x

Odum, H. T. 1956. Primary production in flowing water. Limnol. Oceanogr. 1: 102-117. doi:10.4319/lo.1956.1.2.0102

Olesen, B., S. Enríquez, C. M. Duarte, and K. Sand-Jensen. 2002. Depth-acclimation of photosynthesis, morphology and demography of Posidonia oceanica and Cymodocea nodosa in the Spanish Mediterranean Sea. Mar. Ecol. Prog. Ser. 236: 89-97. doi:10.3354/meps236089

Papageorgiou, N., K. Sigala, and I. Karakassis. 2009. Changes of macrofaunal functional composition at sedimentary habitats in the vicinity of fish farms. Estuar. Coast. Shelf Sci. 83: 561-568. doi:10.1016/j.ecss.2009.05.002

Pasqualini, V., C. Pergent-Martini, P. Clabaut, and G. Pergent. 1998. Mapping of Posidonia oceanica using aerial photographs and side scan sonar: Application off the Island of Corsica (France). Estuar. Coast. Shelf Sci. 47: 359-367. doi: 10.1006/ecss.1998.0361

Perez, T. 2008. Impact des changements climatiques sur la biodiversité en Mer Méditerranée, p. 38. CAR/ASP, Tunis.

Pergent, G., V. Rico-Raimondino, and C. Pergent-Martini. 1997. Fate of primary production in Posidonia oceanica meadows of the Mediterranean. Aquat. Bot. 59: 307-321. doi:10.1016/S0304-3770(97)00052-1

Pergent-Martini, C., V. Rico-Raimondino, and G. Pergent. 1994. Primary production of Posidonia oceanica in the Mediterranean Basin. Mar. Biol. 120: 9-15. https://doi.org/10. 1007/BF00381936 
Romero, J., M. Pérez, M. A. Mateo, and E. Sala. 1994. The belowground organs of the Mediterranean seagrass Posidonia oceanica as a biogeochemical sink. Aquat. Bot. 47: 13-19. doi:10.1016/0304-3770(94)90044-2

Soullard M, and others. 1994. Evolution of the shoot density of the Posidonia seagrass bed of Calvi Bay (Corsica) Vie Milieu 44: 199-201.

Telesca, A., and others. 2015. Seagrass meadows (Posidonia oceanica) distribution and trajectories of change. Sci. Rep. 5: 12505 . doi:10.1038/srep12505

Thyssen, M., and others. 2014. Onset of the spring bloom in the northwestern Mediterranean Sea: Influence of environmental pulse events on the in situ hourly-scale dynamics of the phytoplankton community structure. Front. Microbiol. 5: 387. doi:10.3389/fmicb.2014.00387

Tomasello, A., G. Di Maida, S. Calvo, M. Pirrotta, M. Borra, and G. Procaccini. 2009. Seagrass meadows at the extreme of environmental tolerance: The case of Posidonia oceanica in a semi-enclosed coastal lagoon. Mar. Ecol. 30: 288-300. doi:10.1111/j.1439-0485.2009. 00285.x

Vassallo, P., C. Paoli, A. Rovere, M. Montefalcone, C. Morri, and C. N. Bianchi. 2013. The value of the seagrass Posidonia oceanica: A natural capital assessment. Mar. Pollut. Bull. 75: 157-167. doi:10.1016/j.marpolbul.2013.07.044

Waycott, M., and others. 2009. Accelerating loss of seagrasses across the globe threatens coastal ecosystems. Proc. Natl. Acad. Sci. USA 106: 12377 -12381, DOI: 10.1073/ pnas.0905620106
Williams, S. L. 2007. Introduced species in seagrass ecosystems: Status and concerns. J. Exp. Mar. Bio. Ecol. 350: 89-110. doi:10.1016/j.jembe.2007.05.032

\section{Acknowledgments}

We thank Pierre Lejeune and the STARESO team for logistical support, Thibault Lambert for the PCA, L.-S. Schiettecatte for help in sampling during the first year of the time-series, Véronique Schoemann, Nathalie Gypens and Sylvie Gobert for fruitful discussions, two anonymous reviewers and the associate editor (Núria Marbà) for constructive comments on a previous version of the manuscript. This work was funded by the Fonds National de la Recherche Scientifique (FNRS) (contracts F.4513.06, 2.4.511.09 and 2.4.637.10) and the Territorial Collectivity of Corsica and the Rhone-Mediterranean and Corsica Water Agency (STARECAPMED - Station of reference and research on change of local and global anthropogenic pressures on Mediterranean ecosystem drifts). AVB is a senior research associate at the FNRS.

\section{Author Contribution}

AVB designed the experiment; WC collected and processed the data; WC interpreted the data and drafted the manuscript with substantial inputs from AVB.

\section{Conflict of Interest}

None declared.
Submitted 26 November 2017 Revised 18 April 2018 Accepted 09 July 2018

Associate editor: Núria Marbà 